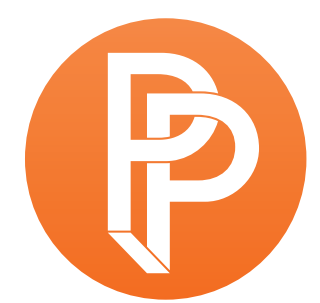

PERFORMANCE

PHILOSOPHY

\title{
THE ESSAY IN TIMES OF CRISIS
}

\author{
JASPERDELBECKE GHENT UNIVERSITY
}

\section{Introduction}

In the 16th century, Michel de Montaigne developed the essay (Montaigne and Screech 1993). It was-and still is-a literary genre characterized by the abrogation of judging, the questioning of authority, the overlaps between fact and fiction, a mixing of styles and a heavy use of quotations. In an age marked by upheaval, Montaigne tried through writing to get a grip on his superfluous time. 'To essay' does not only mean 'to assay' and 'to weigh' but also 'to challenge', 'to test' and 'to attempt'. Montaigne challenged religious, social and political problems in his essays and contested the fixed ideas of his time. The structure of the essay allowed Montaigne to take a critical stance towards his thoughts and actions. 'Am I critical enough towards my own critical thoughts?', this question was a thread throughout Montaigne's years of study and writing. In the following centuries, many authors followed Montaigne's example and brought the essay to the level of an established literary genre. One can trace a consistency in the moments where the genre of the essay gains popularity. The genre of the essay-starting from the turbulent $16^{\text {th }}$ century with Montaigne-flourishes in circumstances of change and insecurity. The generic identity of the essay has always allowed experiment and creativity to writers, philosophers and critics to challenge the doxas of their time. Therefore you can postulate that the essay is not only a symptom of a crisis, but also the product of a crisis.

Considering the subject matter of this thematic issue of Performance Philosophy-'Crisis/Krisis'-I want to survey in the first section of this contribution why the genre and form of the essay flourishes in times of crisis. By 'a society in crisis' I understand a society searching for itself on a 
representational, ideological, philosophical and existential level, a situation that often results in political and social upheaval. Another crucial element that constitutes the breeding ground of the essay is an inability of the conventional artistic and expressive outlets of that time to cope for that particular time. As I will address later in this text, in Montaigne's case it was the inability of the traditional scholastic system that prohibited him from expressing his concerns, thoughts and doubts about what was happening around him.

For this article, I subscribe to the editors' statement that 'the word crisis mutated to a rather banal term, generally understood as "breaking-point", but the underlying web of connections remains the same. While on the surface, "crisis" names a state of panic, a situation to be overcome en route to a better state or health' (Performance Philosophy 2017). With the help of the ideas on the essay by Montaigne, Theodor W. Adorno and György Lukács, I want to open up new possibilities that can help to revaluate the notion of krisis, the act of judging as foregrounded by the editorial team of this Performance Philosophy issue. As the issue of Crisis/Krisis addresses, despite the denotation of 'rupture in the smooth workings of the everyday, the word crisis still carries within it the critical principle of judgement in the increasingly complex, globalized world' (ibid.). I believe that the selfreflexive, open and the polemic characteristics of the essay helps to reassess the importance of judgement in our complex society.

Exploring the critical features of the essay in times of crisis, one has to start with Montaigne. Thanks to his Essais, a new way of writing and thinking entered the French literary tradition. But although the essay became an established literary genre, a theory on and of the essay was lacking. We had to wait until the beginning of the $20^{\text {th }}$ century for a convincing theorization of the essay. In this context, the work of Lukács and Adorno on the essay cannot be ignored. The exploration of Montaigne's, Lukács's and Adorno's ideas on the essay will help to understand the second section of this text, where I elaborate on the extension of the written essay to film and the performing arts.

Under the influence of Lukács's and Adorno's ideas, the critical qualities of the written essay did not remain unnoticed by other artistic disciplines. Experimental film and documentary makers borrowed strategies and methods from the written essay and adapted them to their artistic practices. The translation of the written essay to experimental film was termed the 'essay film', a genuine concept within film studies today.

Today we observe a similar trend within performance practices in the field of performing arts. ${ }^{1}$ Especially, within the current field of contemporary documentary theatre, the essay is rising to prominence. The nature and the purpose of the essay inspired artists with a strong documentary approach in their artistic practice. The interest in the essay coincides in my view with a 'new documentary turn' in performing arts (Forsyth and Megson 2009; Martin 2013; Irmer 2006). It is a tendency where 'more complex and hybrid forms of representation' emerge and pose problems about 'the status of the image', 'the relation with the world beyond the imagination of artists' and 'continuously provoke debates concerning the production, representation and status of knowledge, truth and reality' (Le Roy and Vanderbeeken 2016). This recent tendency differs from the common sense understanding of the documentary. Traditionally, the documentary is 
concerned with the arrangement of facts to produce an objective view of a situation. Over the years, this conception of the documentary that displays an objective representation of a certain event is undermined and is well described in the work of Bill Nichols (2010) and Stella Bruzzi (2000). They see the documentary as a perpetual negotiation between the real event and its representation. By taking into account this relation, the performative dimension of the documentary rises to the surface, challenges the notion of objective reality and articulates notions of authorship, construction or ideology. Nichols and Bruzzi generated their analyses from documentary films but many of their ideas trickled into theatre and performance studies. So regardless of the field-film or theatre-the documentary today is more than ever concerned with the representations of the real, its modes of production and the control of flow of images. Contemporary theatre makers with a documentary approach have the ambition to intervene in the world in order to reengage and reinvent the way reality is represented.

And here enters the essay again. In my doctoral research, I engage the form, discourse and legacy of the essay to create an additional framework to observe and analyse these kinds of documentary theatrical and performative practices. Many of the artistic strategies and structures employed by artists bears resemblance with the written and cinematic essay. By deriving ideas from the work on the essay in literary and film studies, I explore and trace how the essay appears within theatre and performance. After the second section of this contribution, which is a brief introduction to the genealogy of the essay's translation into film and theatre, I will focus in the third section of this article on Mining Stories (2015), a documentary performance by Belgian theatre makers Silke Huysmans and Hannes Dereere. The duo investigated in their performance the role of memory, emotion, narrativity, power structures and economics in the traumatic aftermath of a mining accident in Brazil. I hope that my exploration of Mining Stories not only will unveil the essayistic nature of that performance but will also help to bring us back to that other central notion of this thematic issue: krisis. In the fourth and final section I state, and I hope my analysis of Mining Stories supports that claim, that theatre and performance today can install a renewed interface between crisis and krisis, a new mode of thinking that can help 'to escape the perpetual anxiety of austerity, fear, and conservative thought that so routinely follows crisis' (Performance Philosophy 2017).

\section{The essay, a perpetually changing genre in a perpetually changing world}

Montaigne developed his new literary genre in the middle of the tumultuous 16th century. It was an age marked by upheaval, as Europe got rid of the dogmatic metaphysical ideas of medieval times. Astonished and anxious at the same time, Montaigne continuously observed his perpetual changing world. Through writing, he wanted to challenge the fixed ideas of his time and learn about his own thoughts and actions. The thread, when one observes the history of the essay, is that the genre reveals itself in moments of fundamental existential crisis. In the case of Montaigne, it was a malfunctioning France governed by the royal court and the Catholic Church that made him resort to the family estate in order to question the hegemonic structures of his time and, most importantly, to analyse his own thoughts and actions within these dominant structures. The interplay between fact and fiction and the usage of quoting enabled Montaigne to interrogate the 
status of authority of key thinkers that influenced his time. Juxtaposing specific quotations of Greek thinkers or deliberately changing the author's name, Montaigne problematized values and ideas people in his time took for granted. By embedding quotation as an artistic strategy, Montaigne introduced a dialogical relation that tried to connect and encounter his age with that of the author's. This dialogical dimension is articulated by the clear presence of an 'l', Montaigne as the essay's writer. By explicitly marking his own position, Montaigne invites the reader to join him in the journey he makes in his essays. Montaigne started his essay writing as a 'therapeutic practice' wherein he wanted to 'reflect on his own thinking, not in order to understand the world around him, but to comprehend his own position in this world' (Roose 2017, 72). But at the same time, these reflective and meandering writings indicated for Montaigne how 'limited his critical thinking was' when it came up against the fundamental changes and paradigm shifts of his time (101). Montaigne's continuous act of essaying became 'a reflection of and on the changing self in the changing world' (Good 1988, 23).

As Claire De Obaldia pointed out, the Essais are a typical product of the Renaissance: a society in transition from a collective tradition to the focus on individuality and originality. The essay marked at that time the philosophical and ideological shift from 'the reign of the universal to the particular' $(1995,65)$. De Obaldia is not surprised by Montaigne's scepticism and critical attitude towards his time, caught in two eras. It was a time of 'deep epistemological anxiety', a time when 'allegiance to the past is progressively overtaken by acute reflections' regarding the problem of originality and authorship (ibid.). So Montaigne's new style of writing was not only a reaction to a society in political and religious crisis; it was also a reaction against the traditional forms of literature and the classical methods of learning and epistemology. The essay became a literary vehicle where knowledge was based on experience and not on the orthodoxy of common opinions. Montaigne's concern with the foundations and criteria of truth, the conditions of meaning and the question of representation resulted in a literary form where the writer was allowed 'to freely think outside the constraints of established authority and traditional rhetorical forms' (Hall 1989, 78).

Montaigne's therapeutic project influenced a number of future writers and philosophers. The Essais were the precursors of the modern essay but differ with what the essay is and wants to be in modern times. 'Whereas Montaigne wrote with one eye on the world and the other on himself', Lane Kauffmann recaps, 'the modern essayist works with one eye on the object of study while the other nervously reviews the methods by which he is authorized to know or to interpret' $(1988,69)$. Montaigne's unmethodological methods encouraged future writers and philosophers to pose questions about the foundations of knowledge and truth without premises and prejudices. What Montaigne conveyed were not solutions but criticism as such. Within turbulent times, this act of essaying transforms the mind to 'the site of the imagination', a space that allows 'theory's virtual potential to sight and re-cite what it has already seen' (Kritzman 2009, 2-3).

Montaigne's exploration of human subjectivity influenced $18^{\text {th }}$-century England, a society in an industrial and democratic transition where the essay became a medium to reconfigure the individual. In the coffeehouse culture, the essay becomes a vehicle that 'dramatically troubled subjectivity and representation' by sharing it in the public sphere (Corrigan 2011,19). Essay writing 
became a tool to shape 'a dialogue between a self and a visible world' (18). The new bourgeois culture that started to have influence was very hospitable to the essay. Combined with the empirical and individualistic qualities of English culture, $18^{\text {th }}$-century England was the ideal breeding ground to stabilize an own essay tradition (Good 1988, 135).

In the $19^{\text {th }}$ century, the praxis of essayistic writing spreads itself out among philosophy, autobiographical writing, art criticism and social report. Following the example of Montaigne, the $19^{\text {th }}$-century essay 'tends to refine the moral and political voice of the essay' (Corrigan 2011, 18). In her observation, De Obaldia recognizes in the period of early German Romanticism the same breeding ground as in Montaigne's days. Just as in the Renaissance, it was a time marked by periods of generic transitions, political disintegration and reconfiguration of the discursive system that then lead to a reshuffling and a displacement of generic boundaries $(1995,39)$. From the Romantic perspective, the essay helped them to manage to cope with the transitory period between two 'Golden ages or utopias' (ibid.). To De Obaldia, the parallels with the Renaissance and Romanticism displays that the essay 'is the typical response to a world which has become problematic' (ibid.). She continues:
It is the typical expression of a lack of cultural unity, where man's faculties are exercised in isolation from one another. For the negativity of modern times which the essay embodies is characterized by a split between the 'I' and the world, between subject and object, between particular and universal, between art and philosophy, when all relationships are destroyed and reflected upon. (ibid)

Within such a context of negative conjunctures, the essay functions as a mediator between oppositions. Because of its mediating form, the essay takes a hybrid and marginal position between philosophy and art and is eager to overcome the shortcomings of the traditional modes of knowledge.

By the beginning of the $20^{\text {th }}$ century, we see that the essay is far away from the Montaignian essay, which introduced the modern essay but remained a literary vehicle to explore human subjectivity. Under the impulse of Lukács and especially Adorno, the form of the essay becomes 'the critical form par excellence for the critique of ideology' (Adorno [1958] 1984, 166). This shift explains why the essay takes a more prominent place within literary criticism and philosophy. Lukács's ideas on the essay are related to the crisis of Modernist literature and drama. They express his fascination for the rise of the Modernist ideas in painting and music and were rooted in the vitalist tendency of that time. Max Bense, on the other hand, thought that, after the catastrophes of World War II, the essay was a crucial instrument to revaluate critical thought. He stated that:

Due the critical situation as a whole, due to the crisis in which mind and existence strive, the essay has become a characteristic of our literary era. The essay serves the crisis and its conquest by provoking the mind of experiment, to configure things differently, but it is not simply an accent, a mere expression of the crisis. ([1947] 2017, 59) 
The reassessment of self-reflexivity, the fragmentary, the polemic, the subjective experience and discontinuity of the German essay was what attracted Adorno to the form. With its position between science, philosophy and art, the essay in Germany resisted the reductionist reflexes towards Totality and Truth. Adorno's resistance against Totality and Truth coincided with the arguments he made with Horkheimer in their Dialectic of Enlightenment (1944). They argue there that the scientification of the human experience, the rationalization of society and man's alienation does not emancipate but reduces man to a cog in a machine. One only matters insofar as he works with and in a functionalistic capitalist society. The essays of Simmel, the young Lukács, Kassner and Benjamin were, for Adorno, the paragon of how the speculative dimension of the essay could provide 'a unique combination of empirical knowledge and aesthetic form' (Good 1988,152), because the essay is not a work of art in the full sense, but 'a kind of hybrid of art and science, an aesthetic treatment of material that could otherwise be studied scientifically or systematically' (ibid.).

These features brought Adorno to the conclusion that 'instead of achieving something scientifically, or creating something artistically, the effort of the essay reflects a childlike freedom that catches fire, without scruple, on what others have already done' (ibid.). Herein resonates what Georg Lukács pointed out decades before Adorno:

[...] the essay always speaks of something that has already been given form, or at
least something that has already been there at some time in the past; hence it is
part of the nature of the essay that it does not create new things from an empty
nothingness but only orders those which were once alive. (Lukács [1910] 2010, 26)

What Lukács and Adorno have in common is a mutual aversion towards 'the ideals of purity and cleanliness' dictated by the rigorous scientific disciplines of their time that, 'bear the marks of a repressive order' (Adorno [1958] 1984, 156). By defending the essay and endorsing its qualities, they try to contest the restrictions and traditions of the academic. They oppose the omnipotence of Reason. In its resistance to Totality, Adorno notes that the essay's 'totality is that of non-totality; one that even as form does not assert the thesis of the identity of thought and thing, the thesis which in its own content the essay reject' (165). Philosophy and criticism are in Adorno's view jammed in their own dogmatic attitude towards their solidified concepts and definitions. 'Philosophy has completed the fullest critique of definition from the most diverse perspectives', summarizes Adorno (159). The essay as form offers a medium to inject scepticism towards the dogmas of traditional science and philosophy. By revaluating the changing and the ephemeral, employing experience as preferred reflected form and suspending the traditional concept of method the essay resists what Adorno experiences as 'the philosophy of Absolute knowledge':

Just as such learning remains exposed to error, so does the essay as form; it must pay for its affinity with open intellectual experience by the lack of security, a lack which the norm of established thought fears like death. It is not so much that the essay ignores indisputable certainty, as that it abrogates the ideal. The essay becomes true in its progress, which drives it beyond itself, and not in a hoarding obsession with fundamentals. (161) 
The obsession for Absolute knowledge that is attacked by Adorno applies to a similar obsession with Truth. Opposed to the notion of 'truth as a network of causes and effects, the essay insists that a matter be considered, from the very first, in its whole complexity; it counteracts that hardened primitiveness that always allies itself with reason's current form' (162). To break this tradition, Adorno suggests that, 'for whoever criticizes must necessarily experiment; he must create conditions under which an object is newly seen' (166). Adorno's call to create new conditions recalls to Montaigne's venture. The latter had the same sense of urgency to create within the field of literature a new type or mode of literature that enabled him to question those issues he wanted to be addressed but the existing literary tools were inadequate to do so. By allowing association, ambiguity of words and neglecting the logical synthesis, the essay makes the auditor an accessory in its process of truth making. Or as Adorno describes this process:

\section{In the essay discreetly separated elements enter into a readable context; it erects no scaffolding, no edifice. Through their own movement the elements crystallize into a configuration. It is a force field, just as under the essay's glance every intellectual artefact must transform itself into a force field. (161)}

This force field where separated elements encounter each other, becomes the field of critical thought: 'through the confrontation of texts with their own emphatic concept, with the truth that each text intends even in spite of itself, it shatters the claim of culture and moves it to remember its untruth' (168). Adorno's plea for the discursive form of the essay could be seen as arbitrary or as a hybrid lacking a convincing and independent tradition. The essay's vague openness of feeling and mood could be perceived as naïve. After all, how does the entanglement of elements, as interwoven as a carpet, enables us to judge?

And this question brings us back to the notion of krisis. In our age, where many of the crises we face are not one-dimensional but exist within a complex web of elements and interests that are predominantly transnational, geopolitical and in constant flux, how can we judge? The ways mainstream media report and represent these crises preserve the simplifications of reality and encumber nuanced debates and dialogues about how to cope with certain crises we face today. Today, swift judging and the inability to question and challenge one's own convictions and beliefs replace Krisis-as-judgment, 'the rigorous mental activity of judgement through which verdicts' are made (Performance Philosophy 2017). So how can the essay serve to reassess this notion of krisisas-judgment?

Referring to what Adorno stated earlier, when the essay creates its own rules, guidelines and conditions, how can we judge? 'Who gives him the right to judge', ripostes Lukács ([1910] 2010, 26). To Lukács, the essay is a mere precursor of a judgement. Just like an artwork, the essay faces life with the gesture of an artwork. But it only remains a gesture, an attitude. The essay inhabits that which judges and that which is judged. Thus Lukács concludes that 'the essay is a judgment, but the essential, the value-determining thing about it is not the verdict but the process of judging' (34). Judgments may result but in the essay there are no prejudices or prejudgments. Conclusions may arise, but they are not foregone conclusions, they remain provisional and speculative. 
In order to avoid the danger of acting 'as if it held the philosopher's stone in hand', the essay in Adorno's conceptualization lacks a standpoint towards the concepts, experiences and theories it touches and absorbs ([1958] 1984, 166). Only by not taking a clear stance towards its subject, the essay can 'polarize the opaque, to unbind the power latent in it' and construct 'the interwovenness of concepts in such a way that they can be imagined as themselves interwoven in the object' (170). By avoiding reductionist's reflexes, the essay displays the complexity of things as complexity. In my opinion, this kind of approach, the understanding of complexity as complexity displayed by the form of the essay, enables us to touch different perspectives and share different opinions but in an open and speculative way, without the constant pressure of having a clear opinion or judgment. The venture of the essayist through his subject matter, installs, as addressed here by Lukács, the essay's most significant characteristics when we talk about judging: the sharing of the process of judging. Or to put it in the frame of this context: the sharing of the act of judging, krisis.

\section{The actuality of the essay: from the essay film to the essayistic in contemporary performing arts}

Against this historical background, since the writings of Montaigne, Lukács and Adorno, the essay in the $20^{\text {th }}$ century became a form, a medium and an object for theoretical and philosophical reflections. Although Adorno is most frequently cited when discussing the theorization of the essay, it is the work of his colleague Walter Benjamin that fuelled much of Adorno's thought. Adorno was responsible for the theorization of the essay-one that has had a significant influence-but it was Benjamin who had a serious impact on the $20^{\text {th }}$ century practitioners of the audio-visual form of the written essay (Alter 2007, 48). The essay's flexible, open and transgressive characteristics does not only promote an innovative approach towards its literary tools, it also endorses a translation to artistic disciplines such as film, video and installation art (54-55). Or as I try to explore in my research: into theatre and performance.

Influenced by the criticism of the $20^{\text {th }}$ century, but also the writings of Benjamin, many experimental film and documentary makers discovered the essay and its possibilities to derive from the literary genre what could serve them in their artistic praxis. Cinema's resort to the essay was seen as an attempt to encapsulate the 'sublimely paradoxical wish to communicate directly with the spectator, to bypass the obvious constraints of an apparatus' (Rascaroli 2009, 191). Thanks to technological improvements, the camera became just like a pen: 'increasingly flexible, portable and responsive to human thought' (Rascaroli 2017, 4). The translation of the written essay to experimental cinema and documentary film was termed as the 'essay film'. But it took more than Benjamin's writings, experimental freedom and new forms of production and distribution to pave the way for the proliferation of essay films. As Timothy Corrigan indicates, the essay film addresses a crisis in both representation and the definition of cinema in all of its aspects within the powerwar environment: social, economic, cultural, ideological and institutional (2011, 7). Cinematic essays emerge when Europe was a landscape of ruin. The economic and political crisis after World War II, the stories of the Holocaust, the failure of the promise of totalising systems and the Modern 
project in general galvanized a social, existential and representational crisis that amplified the essayistic imperative (63). 'The power of the essay' herein, argues Corrigan, is its 'representational agency that emphasizes its ephemerality rather than permanency' (66).

The genealogy of the essay film begins in the first half of the $20^{\text {th }}$ century when avant-garde cinema and documentary film intersected. But it is documentary maker Hans Richter who introduced the term 'essay film' in 1940 to describe a new type of intellectual but also emotional cinema that employed more expressive means into documentary film. Richter describes the rise of the essay in film as 'an attempt to make the invisible world of imagination, thoughts and ideas visible' (Richter [1940] 2017, 91). The transgressive qualities of the essay film as new cinematographic form managed to merge intellect and emotion, subjectivity and objectivity within the documentary genre. Because filmmakers were no longer bound to the traditional parameters and rules of documentary making, the essay film gave 'free reign to the imagination, with all its artistic potentiality'. Because filmmakers were released from chronological sequencing or representational depiction of phenomena, the term 'essay' was chosen to signify 'a composition that is in between categories and as such is transgressive, digressive, playful, contradictory, and political' (Alter 2003, 7-8).

In a few decades, this tendency towards the essay resulted in a vivid and rapidly evolving genre. Essay film became a genre that 'articulates the formal and the aesthetic with the historical and the political' (Alter 1996, 166). Because of these intersections, film critic Paul Arthur noted that the essay film mirrors how human experience and thinking occurs and evolves. 'The essay offers a range of politically charged visions uniquely able to blend abstract ideas with concrete realities' $(2003,58)$. By the essay's crucial questioning of authority and its process-oriented emphasis, the essay film begins to address the complex relationship between words and images in order to undermine the traditional signification of these elements. It is not surprising to film theoretician Michael Renov that, given societies growing complexity, the essay has received renewed critical attention since the 1990s. He observes that the pedigreed essayistic characteristics of the essay such as 'hybridity, non-identity, contingency, indeterminacy and the reflective' more then ever resonate with 'the prevailing theoretical paradigms and with our social life' $(2017,173)$.

Even today, this feature of the essay - being the symptom and the product of a crisis at the same time-is still present. Hence, we have to understand the essay's political function 'not as therapy or healing the wounds produced by the upheavals of the day, but as crisis diagnosis enabling and encouraging future social and cultural transformation' (Alter 2007, 51). In our times governed by a neoliberal hegemony and confronted with mass migration, growing inequality and ecological disasters, the traditional and convincing social narratives are out-dated. As Laura Rascaroli observes, the essay 'invites different forms of expression, and different dimensions and ways of engagement with the real-ways that are more contingent, marginal, autobiographical, even private' $(2009,190)$. These essayistic engagements denaturalize events and representations of the accepted ways of viewing and understanding the world. Therefore, recapitulates Alter, the essay is more than a mere product of critical thinking and writing. The interest in the essay, its evolution 
and transition towards other artistic disciplines indicate that 'essayism is not just a mode of producing-it is a method of reading, viewing and interpreting' (Alter 2018, 16).

In the following section, I trace how the critical qualities of the essay are present in the performance Mining Stories and thereby move from essay film to the essay in theatre. The performance is an example of what I described in the introduction as a 'new documentary turn' within the performing arts field. In their own manner, Huysmans and Dereere continuously try to question, abrogate and postpone the process of judging in Mining Stories. They intend to survey the mental apparatus that navigates the process of judging by deconstructing our dominant mode of thinking. I hope that their essayistic approach to the subject matter illustrates how the form of the essay in performance could help us to revaluate the notion of krisis-as-judgment.

\section{Tracing the essay in Mining Stories by Hannes Dereere and Silke Huysmans}

On the 5th of November 2015, a dam containing toxic waste built by mining company Samarco collapsed in Minas Gerais, a mountainous region in Brazil. A flood of toxic waste thundered down the hills. Within minutes, houses and small villages were completely destroyed. The official investigation of the Brazilian authorities showed that Samarco was responsible for the economic, ecologic and human disaster. The company was aware of the decay of the dam but never took the necessary safety measures to assure the security of the region and its inhabitants. Samarco got away clean because their economic activities provide a steady income for the thousands of poor households in the region. In return, the mining company compensated the people who had lost family members and property, but never compensated the ecological damage that it caused due to their negligence. Apart from the human damage, the region is caught up in an environmental crisis that will have an impact on the rivers and small creeks for years.

15 February 2016. After three months, Samarco re-started their economic activities. Business as usual. The people of Minas Gerais tried to turn the page but the emotional traumas, the ecological disaster, and the sad stories remained. What was stunning, and even shocking, was Samarco's publicity campaign launched that very same day entitled, 'We have to look at this event from different perspectives'. By setting up a big media campaign and manipulating politicians, Samarco tried to control the public debate about the catastrophe. Doing this, Samarco imposed their version of the events and installed a dominant narrative wherein everybody had a responsibility in the disaster.

As a reaction, Belgian theatre makers Silke Huysmans and Hannes Dereere took Samarco's call to heart, went to Brazil and listened to the different perspectives on the disaster. They spent months in the affected region and collected hours of field recordings containing the testimonies of people who lost friends and families, local politicians and the Samarco management. Apart from listening to those who were directly affected by the disaster, the duo also encountered ecological activists, economists and specialists in trauma recovery. Talking to these 'outsiders' enabled the artists to create a meta-perspective to survey what kind of underlying mechanisms cause these kind of events and how those affected by environmental disasters cope in the aftermath. 


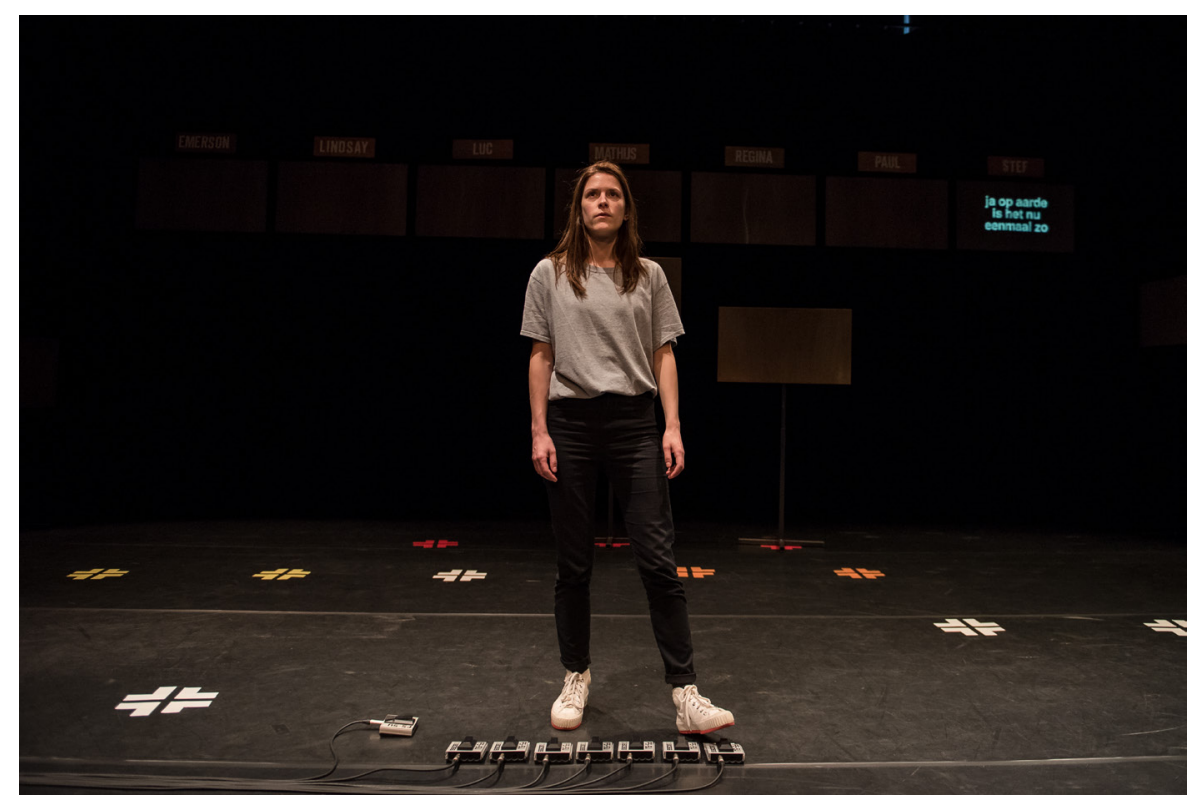

Image 1: Loop Station, from Mining Stories (2015) by Silke Huysmans and Hannes Dereere. Photograph by William van der Voort

It was not Dereere's and Huysmans's aim to give a voice to the victims of the disaster. Their approach endeavoured to treat each story and testimony as equal, in order to avoid crafting another master-narrative that would overshadow the multiple perspectives on the event. The performance Mining Stories became an instrument to interrogate Samarco's dominant narrativeeverybody is partly responsible-imposed by the firm's publicity campaign launched in the aftermath of the disaster and to explore the mechanisms that caused the disaster. For Dereere and Huysmans, the stories of pain, despair and anxiety for what the future will bring were the starting point to go beyond the events in Minas Gerais and address the precarious economical and ecological situations that we find all over the world.

Based on my observations on how the artists set to work with their documentation and the translation into the performance, I term Mining Stories 'essayistic', according to its artistic strategies and the purpose of the theatre makers. A first feature that brings me to this conclusion is the position of the author/performer on stage. The performer is an enunciating subject that stresses the authorial presence in order to question and problematize the veracity of the subject matter, the notion of authorship and subjectivity in general. In Mining Stories, Huysmans steps on stage, assisted by a loop station that she uses to start playing audio samples of the recorded conversations (Image 1). The words of the interviewees are projected on wooden panels flanking the sole performer. We hear an economist, a specialist in traumas, a neuropsychologist, an ecological activist and a jurist. Five different voices commenting on issues that have no direct relation to the disaster. They talk about how the process of remembering and recollecting memories works, about economic growth and the significance of storytelling. This 'methodically unmethodical' character of the essay is a key element in the theatrical essay of Huysmans and Dereere (Verschaffel 1995, 11). 
By starting the performance by creating a distance towards the catastrophe, the artists try to go beyond the mere anecdotes and stress the complex web of human emotions, political interests, ethical questions and social issues that are interwoven with disastrous events such as in Minas Gerais. In their attempt not to stage and represent a mere collection of testimony of the victims, the performance addresses and questions fundamental economic mechanisms, political hegemonies and problematic power relations that are at the basis of such ecological catastrophes. The disastrous event itself is, in fact, never discussed during the performance. The stories we hear are about the post-event: feelings that popped up afterwards, the traumas that came to light, the sneaky procedures that were started by the government and the mining company in order to forget everything that happened as soon as possible. By reciting these different perspectives and blending abstract ideas with concrete realities in a non-linear way, Mining Stories avoids the danger of a linear and simplified narrativization of the disaster. The performer's actions and gestures on stage while using the looping station are a crucial element the attempt to avoid the pitfall.

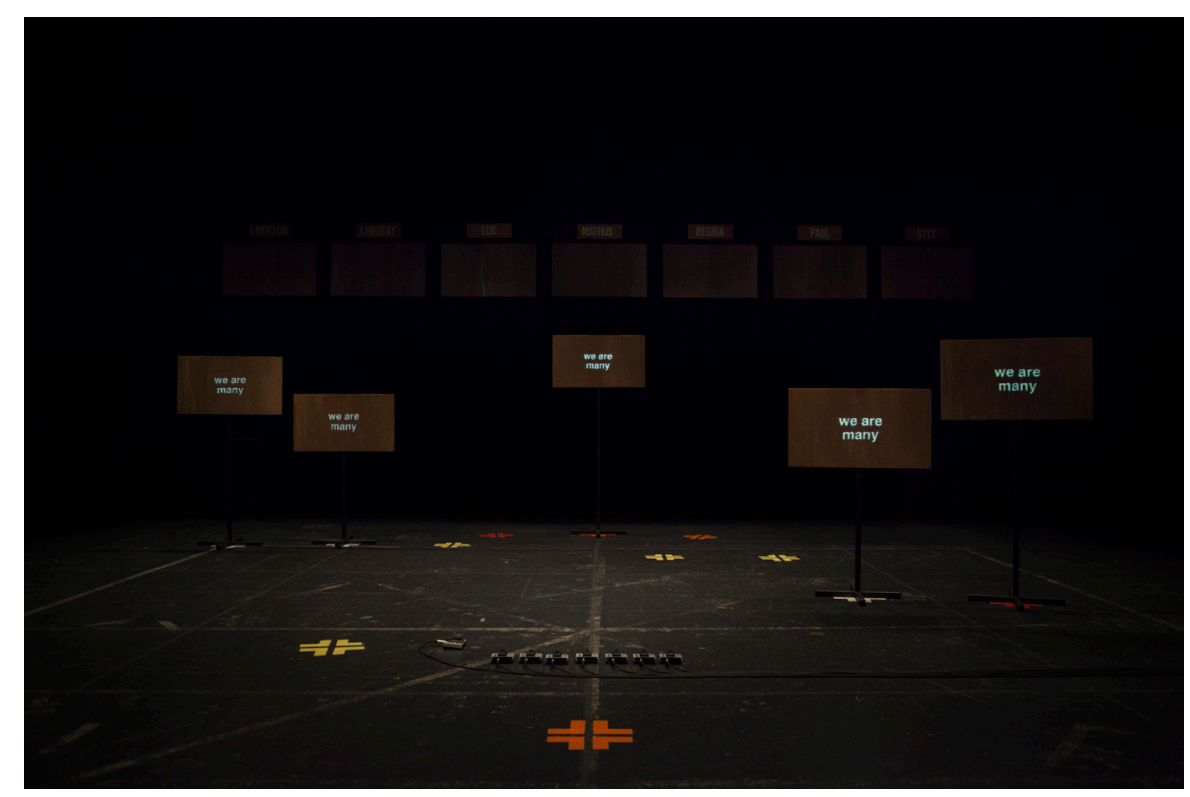

Image 2: Many Voices, from Mining Stories (2015) by Silke Huysmans and Hannes Dereere. Photograph by Tom Callemin

As a DJ, Huysmans finds a way through the conversations, opinions and statements. The audience observes how she makes her own associations. Performing live on stage, she is at once 'a critic and a metahistorian, whose engagement with an object is a reflection on the gap-be it cognitive, temporal, cultural, experiential-that distances him or her from that object' and a reflection on how theatre may help to negotiate such a gap (Rascaroli 2017, 189). But the biographical element of the performer of Mining Stories challenges this critical position. Huysmans was born in the affected region and spent the first seven years of her life in Mariana, one of the villages that was washed away in 2015. The performer's dual position-as being from, and thus emotionally attached to, that area but also a critical and distanced spectator-articulates 'the question [of] where the essayist should be positioned in relation to the story be told [...], because querying the narrating stance and its ethos (its proximity to/distance from the story) is part of the essay's self- 
evaluative process' (152). By making Huysman's subjective position explicit, the essayistic approach implemented in Mining Stories problematizes the dominant narrative of the events imposed by Samarco 'through the disintegration of narrative agency, the exploration of the margins of narrative temporality as history and the questioning of the teleological knowledge that has conventionally sustained and shaped narrative' (Corrigan 2016, 16).

In this theatrical essay, the explicit mental conversation between performer and the spectators triggers a dialogical relationship that becomes what Laura Rascaroli described as an 'act of constant interpellation'. Within this process you as a spectator are 'called upon to engage in a dialogical relationship with the enunciator, hence to become active, intellectually and emotionally, and to interact' with what is performed $(2009,35)$. The mix of the stories by Huysmans in order to create certain associations is an open invitation to the spectators to join Huysmans in the process of montage and associations. It is challenging for the audience to cope with the poetic interplay of voices. Mining Stories, as a theatrical essay, is written by pressing the pedals of the looping station. By implementing this essayistic strategy via contemporary technology, the spectator is tempted to make his own associations, just like Huysmans does as the performer. This invitation to take a more active role should prevent the spectator from becoming overwhelmed and paralyzed by the opinions and statements heard throughout the performance. The essay invites their readers and spectators to relate to what is (re)presented. Including readers and spectators in 'a true conversation', allows them 'to follow thorough mental processes of contradiction and digression', breaks 'the neutral contract of spectatorship' and forces them 'to acknowledge a conversation, along with its responsibilities' (Lopate 1996, 19). Just like in other essays, the spectator in Mining Stories becomes 'an explicit partner in the communicative negotiation; he is overtly asked to enter into dialogue; and to contribute to the creation of a constitutively open and unstable textual meaning' (Rascaroli 2009, 189). The use of quotation and collage and the mixing and matching styles reinforces the dialogical dimension. By juxtaposing facts, quotes and styles Mining Stories results in a 'heterogeneous collection of shreds and memories in search of a place where a bashful subject can appear' (Verschaffel 1995, 11).

The implicit invitation towards the audience to join Huysmans in the journey through the stories and events of Minas Gerais is an invitation to join in a quest where our thoughts and actions are being explored and scrutinized. The flood of information makes it impossible to digest and analyse everything that could enable an outsider to judge the situation in terms of responsibility or causality. On the contrary, their essayistic approach leaves space for failure and doubt and offers a possibility for stories of the performance to resonate with the stories of the spectators. Mining Stories displays that, once having heard the complexity of the subject matter, it is impossible to judge objectively without being reductive or deficient. As a spectator, being confronted with the stories and the complex web of causes and (shared) responsibilities that are part of what happened in Minas Gerais can be overwhelming. But at the same time, you are invited to, as Huysmans does, 'reclaim an active subjectivity as a kind of editor seeking a face, where to edit means to investigate or to open events with an opinion, thought, or idea' (Corrigan 2011, 171). Thinking through the events of Minas Gerais, Mining Stories implicitly demonstrates a form or a place of agency. It is a subtle invitation to the individual spectator to copy and paste, to question and to work a way 
through the complexity. The outcome of the concatenation of stories is an appeal to relate, individually and collectively, to similar situations in the world. The format of the essay is a genre par excellence that could make people aware of their shared responsibilities and the power they have to react. This focus on agency expresses the aim and desire of the essay to construct 'a speaking "I" who is inquisitive, pensive, searching and self-searching, engaged and self-reflexive. It is an "I" who wishes to address and engage within a shared space of embodied subjectivity' (Rascaroli 2009, 191).

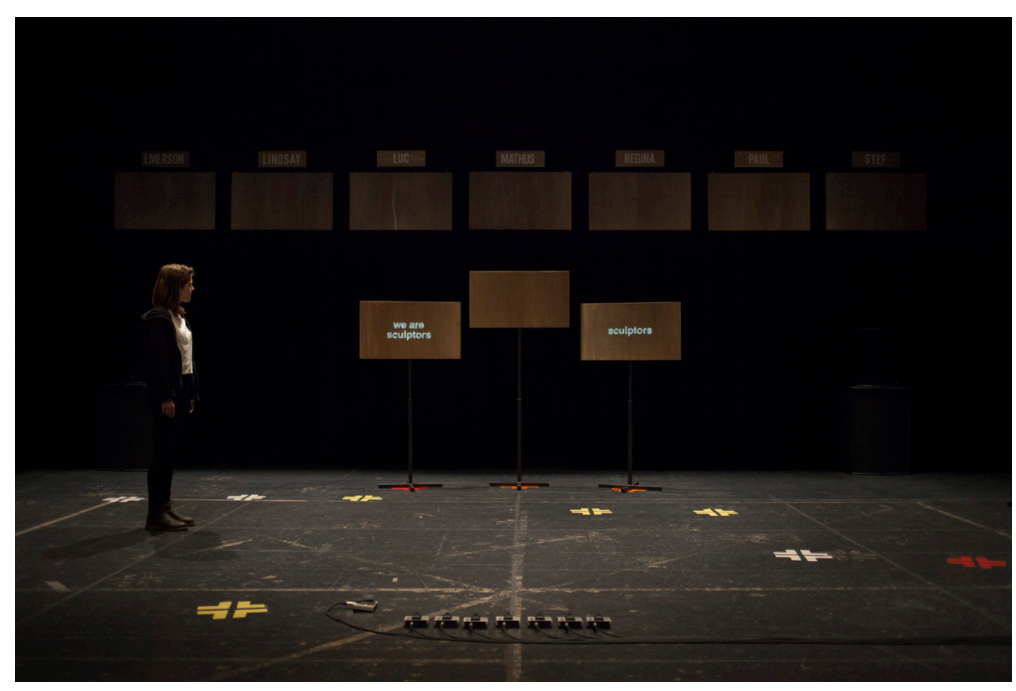

\section{Image 3: Speaking '1', from Mining Stories (2015) by Silke Huysmans and Hannes Dereere. Photograph by Tom Callemin}

Already since Montaigne introduced the essay, the essayistic practice operates as 'an investigation into the truth and ethics of social events and behaviour' and as 'an editorial intervention in the news of everyday history' (Corrigan 2011, 154). In Mining Stories this editorial dimension is articulated in order to 'unveil and analyse not only the realities and facts that are documented but also the subjective agencies of those realities and facts' (155). Within their essayistic approach, Dereere and Huysmans articulate 'the necessary play of consciously and decisively mobile subjectivities within those reports, reports not only about facts, realities, people, and places discovered and revealed but also about the possibility of agency itself within a state of current affairs that is no longer transparent nor easily accessible' (ibid.). Herein distinguishes the essay itself from the genre of the documentary, whereas the latter claims to 'present unambiguous truth and a relationship to history that is not arbitrary, the essay allows for contradictions and play' (Alter 2007, 52).

\section{With a little help from the essay: from crisis to Krisis}

In the last paragraph of The Essay as Form, Adorno wonders what the significance is of the essay for his time: 'the relevance of the essay is that of anachronism. The hour is more unfavourable to it than ever' ([1958] 1984, 170). Adorno's statement denounces the essay's unfortunate position, 'crushed between an organized science, in which everyone presumes to control everyone and 
everything else' and philosophy (ibid.). When we take his claim to our current times, we may conclude that criticism in general is under pressure. In an age governed and dictated by anxiety, austerity and conservative thought the urge and desire to revaluate and inject the critical qualities of the essay are-at least according to my observations-more pertinent and urgent than ever. Since Montaigne, the essay -in its written or cinematic form-has always fulfilled a pioneering role in generating new engagements with the real, to recite Rascaroli. The further evolution of the written essay and its translation into the essay film demonstrates that the essay continues to be an inspirational form and medium to encounter.

Our 'current standstill' is not only a social, economic, ecological, political, philosophical or ideological crisis. Following Corrigan's earlier analysis, we are (still) finding ourselves above all in a representational crisis. Although our globalized world is getting more complex, and our social, economic, ecological and political problems are entwined, we won't be able to dismantle or overcome this complexity in the near future. The crisis we are facing today is not because of complexity itself but because of our inability to cope with complexity. Anxiety, fear and uncertainty are not problematic. These are genuine human emotions in a society that is rapidly changing on a demographic, social, ethnic, religious and economic level. Our human apparatus that should help us to deal with these transformations is in crisis as well. The complexity of our times and the human emotions in reaction to this complexity is being influenced and exploited by mass media, malicious politicians and corporate interests.

Just as Montaigne, and many after him, tried in their times of crisis, I believe that the essay can operate as an vehicle to break the hegemonic structure that precludes us from dealing with our complex world. With the example of Mining Stories I have tried to pronounce that the essay-in a theatrical and performative form—can prevent us from passing swift judgements. Instead, the performance suspends the verdict and offers a mental space for a process of judging in order to reclaim the notion of krisis, the act-of-judging. With Mining Stories, Dereere and Huysmans pronounces the importance of taking into account conflictual opinions, the complexity of our times and the restrictions of our own judgment. In the approach of the subject matter addressed by Mining Stories we don't find answers to overcome or to prevent these kinds of situations. In its modesty, the essay only offers ways to cope with complexity, not to overcome complexity. Within the essay's modesty lies the key for the essay to be the form par excellence to deal with the complexity of our transitory society and to resist the dominant mode of thinking. Characteristic of the latter is the superficial and callous way of judging encouraged and exhilarated by social media. This mode of thinking brought us to a situation that is ruled by oppositions, hostility towards different opinions and the obstinate defence of one's own individual beliefs.

The reason why I think the essay offers a welcome alternative to this dominant mode of thinkingone that does not make our relation to complexity easier-is because the essay offers neither a new Truth nor a Totality. In its mediating form and seen from its Adornian 'childlike freedom', the essay suggests the conception of alternatives with what is already available. Adorno's metaphor expresses the essay's careful and modest attempt to browse through what is seemingly lost, forgotten, secured or achieved. Or as Timothy Corrigan uttered: 'the essay does not create new 
forms of subjectivity, realism, or narratives: it rethinks existing ones as dialogue of ideas' (Corrigan 2010, 219). The childlike element is incorporated in the improvident and almost naïve way of exploring a subject. The essay is not aspiring for impressive truth claims. It rather wants to discover new ideas by sharing a process of thinking. By abrogating the obligation and pressure to conclude a text with a vigorous analysis, a convincing statement or a strong opinion, the essay allows a freedom and openness that is vital for the occurrence of critical thought. Based on my own observations and understandings, today the philosophy of the essay is experienced as a relief because of its attention and care for how ideas and discourses germinate and grow. especially because of the incorporation of thoughts on how these ideas and discourses can be challenged, troubled or even fail. It is a welcome alternative for the superficial thinking and the swift judging luxuriating in times dictated by mainstream media. In contrast to the latter, the essay takes time to explore the complexity of a subject matter, to be carried away trough divergent opinions and to be admitted to stay in a state of uncertainty. And this speculative motion can lead to a judgment, to a new discovery but it can also end up in failure or disappointment.

\title{
Notes
}

\begin{abstract}
${ }^{1}$ Given the topic of this thematic issue of Performance Philosophy, I would like to focus on the breeding ground of the essay instead of the genealogy of the essay and its translation in theatre and performance today. For more details and background information, I would like to refer to a text that recently appeared in Performance Research (Delbecke 2018). The Performance Research text was written as preparation for my PhD proposal. It was a first attempt to share my ideas preliminary to my doctoral research. Building on the legacy of the literary essay and its cinematic offspring, I wanted to construct a modest framework to observe how the essay appears in contemporary performing arts. What are the intersections between the essay in performing arts and its literary and cinematic predecessors? Rather than developing a theory of 'essay theatre', it is my aim in my doctoral research to trace and detect how the strategies of the essay are adopted. The context wherein the essay germinates, grows and is expressed is a crucial element to address in the genealogy of the essay.
\end{abstract}

\section{Works Cited}

Adorno, Theodor W. (1958) 1984. "The Essay as Form." New German Critique 32: 151-171. https://doi.org/10.2307/488160

Alter, Nora M. 1996. "The Political Im/perceptible in the Essay Film: Farocki's Images of the World and the Inscription of War." New German Critique 68: 165-192.

2007. "Translating the Essay into Film and Installation." Journal of Visual Culture 6 (1): 44-57. https://doi.org/10.1177/1470412907075068

2018. The Essay Film After Fact and Fiction. New York: Columbia University Press.

Arthur, Paul. 2003. "Essay Questions: From Alain Renais to Michael Moore." Film Comment 39 (1): 58-63.

Bense, Max. (1947) 2017. "On the Essay and its Prose." In Essays on the Essay Film. Edited by Nora M. Alter and Timothy Corrigan, 49-59. New York: Columbia University Press. https://doi.org/10.7312/alte17266-004

Bruzzi, Stella. 2000. New Documentary: A critical introduction. New York: Routledge.

Corrigan, Timothy. 2010. "The Essay Film as a Cinema of Ideas." In Global Art Cinema: New Theories and Histories. Edited by Rosalind Galt and Karl Schoonover, 218-237. New York: Oxford University Press.

2011. The Essay Film: From Montaigne, after Marker. New York: Oxford University Press. 
De Certeau, Michel. (1986) 2000. "Montaigne's 'Of Cannibals': The Savage 'I."' In Heterologies. Discourse on the Other, 67-79. Minneapolis: University of Minnesota Press.

De Obaldia, Claire. 1995. The Essayistic Spirit: Literature, Modern Criticism, and the Essay. Oxford: Clarendon.

Delbecke, Jasper. 2018. "Tracing the Essay in Contemporary Performing Arts." Performance Research 23 (2): 5-12. https://doi.org/10.1080/13528165.2018.1464720

Good, Graham. 1988. The Observing Self: Rediscovering the essay. London: Routledge and Kegan Paul.

Hall, Michael L. 1989. "The Emergence of the Essay and the Idea of Discovery." In Essays on the Essay: Redefining the Genre. Edited by Alexander J. Butrym, 73-91. Athens: University of Georgia Press.

Kauffmann, R. Lane. 1988. "The Skewed Path: Essaying as Un-methodical Method." Diogenes 36 (143): 66-92. https://doi.org/10.1177/039219218803614304

Kritzman, D. Lawrence. 2009. The Fabulous Imagination. On Montaigne's Essays. New York: Columbia University Press. https://doi.org/10.7312/krit11992

Lopate, Philip. 1996. "In Search of the Centaur: The Essay Film." In Beyond Document: Essays on Nonfiction Film. Edited by Charles Warren, 243-270. Middletown, CT: Wesleyan University Press.

Lukács, György. (1910) 2010. "On the Nature and Form of the Essay. A Letter to Leo Popper." In Soul \& Form. Edited by György Lukács, John T. Sanders, and Katie Terezakis, 16-34. New York: Columbia University Press.

Lyotard, Jean-François. 1984. The Postmodern Condition: A Report in Knowledge. Minneapolis: University of Minnesota Press.

Montaigne, Michel de, and M. A Screech. 1993. The Complete Essays. London: Penguin.

Nichols, Bill. 2010. Introduction to Documentary. Second Edition. Bloomington: Indiana University Press.

Rascaroli, Laura. 2009. The Personal Camera: Subjective Cinema and the Essay Film. London: Wallflower.

-_- 2017. How The Essay Film Thinks. New York: Oxford University Press. https://doi.org/10.1093/acprof:oso/9780190238247.001.0001

Performance Philosophy. 2017. 'Call for proposals: Performance Philosophy 4.1 "Crisis/Krisis"'. http://www. performancephilosophy.org/journal/announcement/view/3

Richter, Hans. (1940) 2017. "The Film Essay. A New Type of Documentary Film." In Essays on the Essay Film. Edited by Nora M. Alter and Timothy Corrigan, 89-92. New York: Columbia University Press. https://doi.org/10.7312/alte17266-007

Renov, Michael. (1995) 2017. "The Electronic Essay." In Essays on the Essay Film. Edited by Nora M. Alter and Timothy Corrigan, 172-182. New York: Columbia University Press. https://doi.org/10.7312/alte17266-013

Roose, Alexander. 2016. De vrolijke wijsheid: zoeken, denken en leven met Michel de Montaigne. Second Edition. Antwerpen: Polis.

Verschaffel, Bart. 1995. Figuren. Leuven: Van Halewyck.

\section{Biography}

Jasper Delbecke studied theatre and performance studies at Ghent University and Freie Universität Berlin. Since 2015 he is an affiliated researcher at S:PAM (Studies in Performing Arts \& Media) at the Faculty of Arts \& Philosophy of Ghent University (Belgium). Besides his academic praxis, Delbecke works as a freelance dramaturg in Belgium and the Netherlands.

(C) 2018 Jasper Delbecke

Except where otherwise noted, this work is licensed under a Creative Commons Attribution-

NonCommercial-ShareAlike 4.0 International License. 